Members who wish to attend all or part of the Conference should write to the Conference Secretary not later thion March 14th. If possible, estimated time of arrival in $\Lambda$ berystwyth should be given. The Conference Secretary's address is:- Alan Conway, "Florida", Penglais Road, Aberystwyth. Telephone: Aberystwyth 7765 .

\title{
NEWWS OF MEMBERS
}

\section{old Members}

Mr. H. I. Beales (Director of the Survey of Sources for American Studies in the United Kingdom). We are pleased to hear that Mr. Beales is now convalescing from his recent illness and hope that he will soon be restored to good health.

Mr. Marcus Cunliffe at the Center for Advanced Study in the Behavioral Sciences, Stanford, California, is completing his contribution to the "History of American Civilization" series of Chicago University Press under the general editorship of Professor Daniel Boorstin: a study of American history during the period 1789-1837.

Mr. Peter d'A Jones. The note on Mir. d'A Jones which appeared in Bulletin, No. 4, p. 25, should be amended to read:- 1. M.A. (Manchester): temporary Assistant Lecturer in American History and Institutions, University of Manchester. 2. 62, Daisy Bank Road, Victoria Park, Manchester, 14. 3. No ontry. 4. An Economic History of the United States (Routledge and Kegan Paul, London, 1956). 5. Interested in Anerican economic, social and intellectual history.

Mr. Peter Marshall (University of Bristol). We are pleased to note that, in his researches into the influence of Edward Bellany in Great Britain, Mr. Marshall has discovered that the eighty-eight year old editor of the British Bellaryite periodical lives only five miles away from him.

Mr. Herbert Nicholas (New College, Oxford) spent the autumn term in the United States - largely, we understand, at the United Nations.

Mr. George Shepperson's study (with Thomas Price, Lecturer in African Studies, University of Glasgow), Independent African. John Chilembwe and the Origins, Setting and Significance of the Nvasaland Native Rising of 1915 is to be published by Edinburgh University Press in the spring of 1958. The work explores some neglected byways in American Negro history through its examination of John Chilembwe, leader of the Nyasaland Native Rising of 1915, who was educated in a Negro theological serninary in Virginia and was strongly influenced by American Negroes at a time of great racial tension in the United States.

Me. Desmond Tarrant is still at the Department of fmerican Civilization in the University of Pennsylvania where he id dolng the work of Visiting Professor. He pronises the Bulletin an article on James Branch Gabell, the subject of his proposed book.

\section{Publications}

W. R. Brock, The Effect of the Loss of the American Colonies on English Policy (London: "Aids for Teachers" series of the Historical Association, 1957,2s.).

D. W. Brogan, "The United States. Civilian and military power" in Soldiers and Governments. Nine Studies in Civil-Military Relations, edited by Michael Howard (London: Eyre and Spottiswoode. 1957. 21s.). Originally given as a Third Programme broadcast.

D. W. Brogan, "The End of Illusion", The Yale Review (New Haven, Connecticut) XLVII, December 1957, 2, pp. 162-174. An important porsonal statement on the United States in the Sputnik Age.

Charlotte Erickson, Anorican Industry and the European Immigrant. 1850-1885 (Cambridge, Massachusetts: Harvard University Press. Juondon: Oxford University Press. 1957. \$4/.75). An intensely documented study of the reactions of Anerican capital and labour to the contract labour laws in the Unitod States. 
David C. Large, "Cotton in the San Joaquin Valley, a study of government in agriculture", Geopraphical Review (New York), XIVII, July 1957, pp. 365-380.

J. R. Pole, "Suffrage and Representation in Massachusetts: A Statistical Note", The William and Mary Quarterly (Williamsburg, Virginia), XIV, 4, October 1957 .

Frank Thistlethwaite, "The Citadel and the Caravan. Anglo-American Relations in the Twentieth Century", American Quarterly (Philadelphia), Spring 1957. It will be remembered that this was the subject of $\mathrm{Mr}$. Thistlethwaite's provocative address at the 1957 annual conference of the British Association for American Studies.

Frank Thistlethwaite, "The Developmont of the American Communities. 2. North America" and "Rivalries in America. 2. The North American Continent", contributions to Chapters XXI and XXII respectively of The New Cambridge Modern History, Volume VII, The 0ld Regime, 1713-63, edited by J. 0. Lindsay (Cambridge: Cambridge University Press. 1957. 37s. 6d.).

Esmond Wright, Washington and the Arnerican Revolation (London: "Teach Yourself History." series of the English Universities Press. 1957. 8s. 6d.).

- The last two itens will be the subject of a joint-review in the next issue of the Bulletin.

\section{New Members}

\section{Institutional momberships}

Ohio State Library, Columbus, Ohio.

\section{Individual Memberships}

As in previous issues of the Bulletin, in order to save space the following form has been used:- 1. Name, degrees, present post (previous courses in parenthesis). 2. Home address (whore known). 3. Courses given in American studies (where relevant). 4. Publications in American studies (including articles but not reviews). 5. Current interests and research plans in American studies.

The Editor would be grateful if new members would send to him for publication in subsequent Bulletins notice of any corrections and additions to the details which are given below after their names.

1. Michael BROOK, M.A. (Oxford): Assistant Librarian, University of Southampton Library. (Sheffield University Library, 1953-5; Department of Local History and Archives, Sheffield City Libraries, 1955-7.)

15. Emigration, especially with regard to Chartism and other radical movements; Joseph Barker, Anglo-Anerican Radical; American films.

1. Philip Spencer HAFFENDEN, B.A., Ph.D. (London): Lecturer in History, University of Aberdeen. (Commonwealth Fund Fellow, Princeton University, 1955-6; Locturer, Department of History, University of Toronto, 1956-7.)

3. Intends to place increasing emphasis upon the importance of Anglo-American relations in the teaching of British Imperial history.

4. Paper prosented at symposium on American history at Williamsburg, Virginia in 1957 to commenorate tho 350th anniversary of Jamestown: details not yet available of publication. "Inperial centralization under. James II", article promised to The William and Mary Quarterly.

1. Alexander Norman JEFFARES, M.A., Ph.D. (Dublin), M.A., D.Phil. (Oxon.): Professor of English Literature, University of Leeds. (Lecturer in Classics, University of Dublin; Lecturer in English, University of Southampton; Lecturer in English, University of Edinburgh; Professor of English Language and Literature, University of idelaide.)

1. Robert Trelford McKENZIE, B.A. (British Columbia), Ph.D. (London): Reader in Sociology, London School of Economics and Political Science. (Taught history at the Univorsity of British Columbia, 1937-40.)

3. Teaches Ainerican parties, pressure groups, etc., in a post-graduate seminar and in a lecture course on political sociology.

4. Continuing interest in Aimerican politics; but present research project on British politics, "Conservatism and the working classes". 
1. Michael Henry MILLGATE, M.A. (Cantab.): at present doing post-graduate research in American literature at the University of Leeds. (W.E.A. TutorOrganiser in South Lindsey, Lincolnshire, 1953-6; Teaching Fellow, Department of English, University of Michigan, 1956-7.)

2. Bars Hill, Cowes, Isle of Wight.

4. "A good word for England", Partisan Review, Summer 1957; "Workers' Education in the United States", The Highway. The Journal of the Workers' Educational Association, Decernber 1957.

5. Research on "The American Bureaucratic Novel". Working on a book of American impressions.

1. Walter Edward MINCHINTON, B.Sc.Eson.: Lecturer in Social and Economic History, University College of Swansea.

3. Honours course in American history, 1800-1939. Has plans f or a Special Subject on England and the American colonies in the eighteenth century.

5. Interested in the history of the American colonies. Has a study of AngloAmerican commerce in preparation.

1. William V. WALLACE, M.A. (Glasgow), M.A. (London): Assistant in History, University of Aberdeen. (Part-time Lecturer in History, Queen Mary College, London, 1955-7; Lecturer in History, University of Pittsburgh, 1953-4.)

5. Contemporary history, especially the Munich era.

Professor R. L. BRETT (Department of English, University of Hull) and Mr. Louis BILLINGTON (Research student, Department of History, University of Bristol) have also joined the Association. We hope to publish details of their interests and careers in a future issue of the Bulletin.

\section{JOHN BARTLET BREBNER}

The death of John Bartlet Brebner removes from the community of AngloAmerican historical scholarship a beloved and respected figure who will be especially mourned in the British Association for American Studies, not only because many of us were fortunate enough to come within the circle of his friendship, but because he was, in a sense, the Association's prophet.

"Bart" Brobner was one of those rare individuals whose academic interests and personal career are so satisfyingly interwoven as to result, not only in sound learning, but in wisdom; and he was one of a very small number to acquire such stature in the field of North Atlantic history. Born a Canadian of Scottish ancestry, the son of the Registrar of Toronto University, he served during the 1914-18 War in the British Army. As an ex-serviceman, he went up to St. John's College, Oxford where he read history with G. N. Clark, rowed in the first eight, and saw something of the world of post-war London. After returning to the University of Toronto, one of a distinguished vintage of young graduate students and lecturers which included Lester Pearson and D. G. Creighton, he joined the staff at Columbia University in 1927; and from this New York vantage point he mastered the broad sweep of Atlantic history.

It was characteristic of the man that his scholarship should be an integral part of his own personal explorations in the Atlantic world; and as a result, his historical writing has a satisfying unity. In the light of what was to come, his first book, New England Outpost: Acadia before Conquest, published in 1927, like his third, The Neutral Yankees of Nova Scotia, published a decade later, was a deceptively modest study in the interplay of Yankees and Canadians in the colonial period. Six years later came The Explorers of North America, in which he developed that conception of, and technique for writing, history as the movement of peoples in a geographic environment. which he was to perfect in his last two works. In the late thirties Brebner undertook to finish and edit the manuscript of Marcus Hansen's The Mingling of the Canadian and Amorican Peoples, which Hansen's prenature death had left incomplete. This was a labour of piety; for Brebner, always generously responsive, cherished his intellectual, as well as his personal friendships. He ragarded himself in a sense as the disciple of Hansen, that great man whose death robbed migration studies of the full impact of his power; and it was charactoristic of Brebner that he should make Hansen the point of departure for his lectures to the first Fulbright Conference on Anorican Studies at Cambridge. 